\title{
Analysis of Factors Affecting Financial Performance of Property and Real Estate Companies Listed on the Indonesia Stock Exchange
}

\author{
Yuliah $^{1}$, Leni Triana $^{2}$, Rina Nopianti $^{3}$ \\ ${ }^{1,2}$ Management Department, Bina Bangsa University \\ ${ }^{3}$ Accounting Department, Bina Bangsa University
}

\begin{abstract}
An study into the financial performance of property and real estate firms that are publicly traded on the Indonesian Stock Exchange from 2016 to 2020 was conducted. There have been a number of previous financial performance studies. In order to re-examine the theory of financial performance, additional study is required. A total of 52 property and real estate companies participated in the survey. Purposive sampling was used to collect data from 29 sample companies over a fiveyear period (2016-2020), resulting in 145 observations. The information for this study came from a list of firms that could be found on the website of the Indonesian Stock Exchange. The data is analyzed through the use of multiple regression analysis. Following the traditional assumption test, multiple regression analysis and hypothesis testing are performed, respectively. Financial performance is influenced by a number of factors, including capital structure, firm size, and total asset turnover. The capital structure has a significant negative impact on the financial success of a company. The size of a company has minimal impact on its financial performance, but the overall amount of assets it has does.
\end{abstract}

Keywords: Financial Performance, Total Asset Turnover, Capital Structure, Firm Size

\section{INTRODUCTION}

$\mathrm{F}$ inancial performance is a company's financial information within a certain period of time as an achievement of the company's success in managing finances. Information about financial performance can assist investors in making good decisions. ROA is used as an indicator used to assess the company's performance. ROA is used to measure the effectiveness of the company in determining profits. ROA whose value increases indicates that the company's performance is better.

There are several factors that affect financial performance, namely capital structure, Firm Size and total asset turnover. The first factor that is thought to affect financial performance is the capital structure. Capital structure is a comparison between the amount of long-term debt and the company's own capital. In funding the company's activities, the company must be able to combine things that can provide profits from debt capital [1]. This situation reflects capital that is properly regulated in accordance with long-term debt and share capital. The capital structure proxied by Debt to Equity can boost the company's profits and the shareholders will also earn profits.

Some researchers provide evidence that capital structure has a significant effect on company performance [2], [3]. However, in contrast to research by [4] shows that capital structure has no significant effect on financial performance.

The second factor that is thought to affect financial performance is Firm Size. The size of the company is reflected in the total value of the company's assets on the balance sheet at the end of the year. Stages of maturity of the company is described from the large total assets.

The size of the company increases to become an idol of investor confidence in terms of more complete financial information and can improve the company's performance continuously.

Researchers proves that Firm Size has a significant effect on company performance [5], [6]. However, this is in contrast to research by [2], [7], [4] and [8] which prove that Firm Size does not affect company performance. The last factor that is thought to affect financial performance is total asset turnover. This ratio describes the level of accuracy in the way the company's total assets carry out the sales process or provides an indication of asset turnover within a certain period of time. If this ratio increases, it illustrates that the company has increasing efficiency with assets so that sales increase and profits also increase.

Yunita, Susyanti and Wahono's research proves that total asset turnover has a significant effect on company performance [9]. However, it is inversely proportional to the results of Lestari's research [8] which states that total asset turnover does not affect the company's performance.

Looking at previous research, the author raised the title "Factors that affect the financial performance of property and real estate companies listed on the Indonesia Stock Exchange 2016 - 2020".

\section{LITERATURE REVIEW}

Financial Performance (Y) 
Financial performance can be explained by looking at the company's financial statements through its financial ratios [10]. The company's financial success that has occurred is always evaluated so that financial performance is needed. Financial performance is a company's financial assessment through financial analysis techniques to find good or bad financial conditions in companies that determine work performance within a certain time [5].

\section{Capital Structure (X1)}

Capital structure is a design of foreign capital which includes the company's financial portion of debt and own capital in terms of financing an entity [11]. Compared to other companies, the quantity of permanent short-term debt, longterm debt, preferred stock, and common stock is referred to as the capital structure [12]. The combination of obligations from long-term and short-term obligations is referred to as the capital structure [13].

\section{Firm Size (X2)}

The size of the company can be seen from the total assets owned by the company [14]. According [15], Firm Size is an assessment of the company indicated by total assets. While [16]said "Firm Size is an increase in the fact that large companies will have large market action processes, large book values, and high profits".

\section{Total asset turnover (X3)}

According to [17], total assets turnover is the proportion of total assets with sales earned during a certain period. The Total Asset Turnover Ratio assesses asset turnover as a whole because it has the widest coverage [18]. Regardless of the type of business, this ratio can describe the ability of all assets to generate sales. Meanwhile, [9] stated that total asset turnover is a ratio that functions to assess the company's ability to develop by using its assets to achieve the desired sales results.

\section{Hypothesis Development}

\section{Effect of capital structure on financial performance}

According to [11] capital structure is a design of foreign capital which includes the company's financial portion of debt and own capital in terms of financing an entity. A company's operations are financed by financing, so it is important to consider the company's methods of making a profitable combination of using equity and debt funds. It describes the correct capital structure between long-term debt and stock. Capital structure increases company profits, which in turn increases owner's wealth, and enhances good relations with creditors by increasing company wealth.

This research is in line with the research of [2], [3] and [6] which suggest that capital structure significantly influences company performance. However, it is in contrast to [4] which show that capital structure does not significantly affect financial performance.
H1: Capital structure has a positive and significant effect on financial performance

\section{The effect of Firm Size on financial performance}

The size of the company includes an assessment of the company's operational processes which are described from the total value of the company's assets in the financial statements. In terms of total assets, companies with high total assets provide information that the company has reached a maturity level. Changes in the level of financial performance of a company are influenced by its scale. The size of the company can determine whether the company's performance is good or bad. Investors trust large companies more because the company's performance is continuously improved to generate quality profits.

This research is in line with [5] and [6] which suggest that Firm Size significantly affects company performance. However, it is different from the research of [2], [7], [4] and [8] which show that Firm Size has no effect on company performance.

H2: Firm size has a positive and significant effect on financial performance

\section{The effect of total asset turnover on financial performance}

The total asset turnover rate shows the efficiency of all company assets for sales. This ratio measures how much of an asset is used in an activity, or how often an asset changes in a certain period of time. If the ratio tends to rise, this situation is a condition where the company uses assets more effectively to increase sales, which will affect the company's profits.

This research is in line with the research of [9] which shows that Total Asset Turnover has a significant effect on company performance. However, it is different from the research of [17] and [8] which show that Total Asset Turnover has no effect on company performance.

H3: Total asset turnover has a positive and significant effect on financial performance

Effect of capital structure, firm size and total asset turnover on financial performance

Capital structure increases company profits, which in turn increases owner's wealth, and improves good relations with creditors by increasing company wealth.

Investors trust large companies more because the company's performance is continuously improved to generate quality profits.

Total asset turnover shows the efficiency of all company assets for sales. This ratio measures how much of an asset is used in an activity, or how often an asset changes in a certain period of time. If the ratio tends to rise, this situation is a condition where the company uses assets more effectively to increase sales, which will affect the company's profits 
H4: Capital structure, firm size and total asset turnover have a significant effect on financial performance

\section{RESEARCH METHODS}

\section{Research design}

The design of this research is causal research that is useful for revealing the relationship between an event or variable. Causal design or cause-and-effect relationships are the researcher's choice.

\section{Population and Research Sample}

This study takes a population of 52 property and real estate companies. According to the above criteria, the research sample was 29 companies. The research period is 5 years from 2016-2020, so the observations of this research sample are 145 observational data. The sampling technique used was purposive sampling method, namely the technique of determining the sample based on certain criteria.

The criteria used in determining the sample in this study, namely:

1. Property and real estate sector companies listed on the IDX according to the 2016-2020 observation year.

2. The company publishes an annual report that has been audited according to the 2016-2020 observation year period.

3. Property and real estate companies that have a profit during the 2016-2020 observation year

4. Have complete data on capital structure, Firm Size, total asset turnover and company performance according to the variables used in the study.

The reason for limiting it to the financial period of 2020 is due to the Covid pandemic which is getting worse throughout 2021, so the financial statements for that year are considered by the author not to be a reference for this research.

\section{Operational Definition and Measurement of Variables}

Capital structure is how much

Most of the company's debt is financed by the company's capital. This study assesses the capital structure using the Debt to Equity Ratio using the following formula:

DER $=\frac{\text { Total Debt }}{\text { Total Equity }}$

The size of the company includes an assessment of the company's operational processes which are described from the total value of the company's assets in the financial statements.

The Firm Size formula is as follows:

Firm Size $=$ Natural logarithm $($ Total assets $)$

Total asset turnover measures how much assets are used in an activity, or how often assets change over a period of time. In this study, total assets turnover was assessed by the following formula:
Total assets turnover $=\frac{\text { Sales }}{\text { Total Assets }}$

\section{Data Collection Techniques and Instruments}

The data collection instrument used in this study was nonparticipatory observation, namely reading, collecting, and writing data, information, and information that the researcher did not participate in directly, and only as an independent observer [19]. Data is data on the annual financial statements of property and real estate companies that have been listed on the Indonesia Stock Exchange and are in accordance with the criteria for selecting the sample. Statistical software, namely SPSS, is used for data processing.

\section{Data analysis technique}

The data analysis technique used is multiple linear regression analysis, hypothesis testing with t test (partial test) and F test (simultaneous test), as well as analysis of the coefficient of determination.

\section{RESULT}

\section{Descriptive Analysis}

Descriptive statistical analysis is used to understand the description of a data that can be seen from the minimum, maximum, and average values (mean), and standard deviation values of Capital Structure (X1), Firm Size (X2), Total Asset Turnover (X3), and Company Performance (Y).

Tabel 1. Descriptive Statistics

\begin{tabular}{|c|c|c|c|c|c|}
\hline & N & Minimum & Maximum & Mean & $\begin{array}{c}\text { Std. } \\
\text { Deviation }\end{array}$ \\
\hline $\begin{array}{c}\text { Company } \\
\text { Performan } \\
\text { ce (Y) }\end{array}$ & 145 & $-37,52$ & 64,76 & 471,23 & 841,887 \\
\hline $\begin{array}{c}\text { Capital } \\
\text { Structure } \\
\text { (X1) }\end{array}$ & 145 & 4,33 & 309,07 & $7.403,41$ & $6.233,832$ \\
\hline $\begin{array}{c}\text { Firm Size } \\
\text { (X2) }\end{array}$ & 145 & 25,68 & 31,74 & $2.949,66$ & 133,144 \\
\hline $\begin{array}{c}\text { Total } \\
\text { Asset } \\
\text { Turnover } \\
\text { (X3) }\end{array}$ & 145 & 0 & 94 & 17,09 & 11,078 \\
\hline $\begin{array}{c}\text { Valid N } \\
\text { (listwise) }\end{array}$ & 145 & & & & \\
\hline
\end{tabular}

Source: SPSS Processed Data, 2022

1. The minimum value of the company's performance is -37.52 and the maximum value of the company's value is 64.76. Meanwhile, the mean and standard deviation of the company's performance are 471.23 and 841.887 .

2. The minimum value of the capital structure is 4.33 and the maximum value of the capital structure is 309.07. Meanwhile, the mean and standard deviation of the capital structure are 7,703.41 and 6,233.832.

3. The minimum value of the firm size is 25.68 and the maximum value of the firm size is 31.74 . Meanwhile, the mean and standard deviation of firm size are 2,949.66 and 133.144. 
4. The minimum value of the tattoo is 0 and the maximum value of the tattoo is 94 . While the mean and standard deviation of the tattoo are 17.09 and 11.078

\section{Multiple Linear Regression Analysis}

Multiple linear regression analysis was used to determine the magnitude of the influence of the independent variables (independent) namely capital structure, Firm Size and total asset turnover in predicting the dependent variable (dependent) namely financial performance, as well as to see the direction of the positive or negative relationship to the independent variable with the variable. dependent.

Table 2 Results of Multiple Linear Regression Analysis

\begin{tabular}{|c|c|c|c|c|c|}
\hline Model & \multicolumn{2}{|c|}{$\begin{array}{c}\text { Unstandardized } \\
\text { Coefficients }\end{array}$} & $\begin{array}{c}\text { Standardize } \\
\mathbf{d} \\
\text { Coefficients }\end{array}$ & t & Sig. \\
\hline & B & Std. Error & Beta & & \\
\hline $\begin{array}{c}\text { (Consta } \\
\text { nt) }\end{array}$ & -6.957 & 6.519 & & -1.067 & .288 \\
\hline $\mathbf{X 1}$ & -.030 & .005 & -0.391 & -6.535 & .000 \\
\hline $\mathbf{X 2}$ & .270 & .224 & .073 & 1.208 & .229 \\
\hline $\mathbf{X 3}$ & 34.777 & 3.104 & 0.657 & 11.205 & .000 \\
\hline
\end{tabular}

Source: SPSS Processed Data, 2022

The results of multiple linear regression analysis obtained using SPSS are as follows:

1. X1 (capital structure) has a regression coefficient value of -0.030 and has a negative effect on financial performance

2. $\mathrm{X} 2$ (firm size) has a regression coefficient of 0.270 and has no effect on financial performance.

3. X3 (total asset turnover) has a regression coefficient of 34.777 and has a positive effect on financial performance.

Hypothesis testing

\section{Simultaneous Test (F Test)}

The $\mathrm{F}$ test was conducted to see the joint effect of the independent variables on the dependent variable. The significance level used is 5\%.

Table 3 Simultaneous Test Results

\begin{tabular}{|c|c|c|c|c|c|c|}
\hline \multicolumn{2}{|c|}{ Model } & $\begin{array}{c}\text { Sum of } \\
\text { Squares }\end{array}$ & df & $\begin{array}{c}\text { Mean } \\
\text { Square }\end{array}$ & F & Sig. \\
\hline 1 & Regression & 1.731 .082 & 3 & 577.027 & 53.473 & $.000 \mathrm{~b}$ \\
\hline & Residual & 1.467 .567 & 136 & 10.791 & & \\
\hline & Total & 3.198 .648 & 139 & & & \\
\hline
\end{tabular}

a. Dependent Variable: $Y$

b. Predictors: (Constant), X3, X1, X2

Source: SPSS Processed Data, 2022
The t-test was conducted to see the partial effect of the independent variable on the dependent variable with a significance level of $5 \%$.

Based on the results of the $\mathrm{T}$ test from table 1 , it can be concluded as follows:

1. X1 (capital structure) produces a significance value of $0.000<0.05$ so it is proven that the capital structure has a significant effect on financial performance.

2. X2 (firm size) produces a significance value of 0.229 $>0.05$, so it is proven that firm size has no effect on financial performance.

3. X3 (total asset turnover) produces a significance value of $0.000<0.05$, so it is proven that total asset turnover has a significant effect on financial performance.

\section{Coefficient of Determination}

This test was conducted to measure the strength of the independent variables, namely capital structure, Firm Size and asset turnover in revealing the dependent variable, namely financial performance.

Table 4 Results of the Coefficient of Determination

\begin{tabular}{|c|c|c|}
\hline \multicolumn{3}{|c|}{ Model Summary $^{\mathrm{b}}$} \\
\hline Model & R Square & $\begin{array}{c}\text { Adjusted R } \\
\text { Square }\end{array}$ \\
\hline 1 & .541 & .531 \\
\hline \multicolumn{2}{|c|}{ a. Predictors: (Constant), X3, X1, X2 } \\
\hline \multicolumn{3}{|c|}{ b. Dependent Variable: Y } \\
\hline
\end{tabular}

Source: SPSS Processed Data, 2022

Based on Table 4, the coefficient of determination is located in the Adjusted R-Square column of 0.531 which explains all independent variables, namely capital structure, Firm Size and total asset turnover, which affect the financial performance variable by $53.1 \%$, and the remaining $46.9 \%$. influenced by other factors.

\section{DISCUSSION}

\section{Effect of capital structure on financial performance}

According to the results of the partial test, capital structure has a negative and statistically significant impact on financial performance. In order to earn more profits, companies must have a significant amount of capital if they have a large amount of debt. The reverse is also true. The firm should seek to maintain and improve the stability of sales and corporate growth, manage the asset structure of the company, boost profits, and increase financial flexibility in order for the company's capital structure to be as efficient as possible. In keeping with the findings of [7], which found that capital structure has a negative and statistically significant impact on financial performance, this study was conducted. According to [4, however, capital structure has no significant impact on 
financial performance, which is in contrast to the findings of [4].

\section{The effect of Firm Size on financial performance}

From the partial test results, the size of the company has no effect on financial performance. This result occurs because a company with a large size does not necessarily guarantee that the company's financial performance is good because large companies usually do not often add new investments related to company expansion before the company pays its obligations and it is not accompanied by an increase in better management in managing the company. If the company takes the initiative to increase investment, it can increase the maximum profit.

This research is consistent with studies undertaken by [2], [4], [7], [8], which have found that the size of a company does not have a major impact on its performance. This, however, is in contradiction to the findings of research undertaken by [6], which indicates that the size of a company has a major impact on its performance.

\section{The effect of total asset turnover on financial performance}

From the partial test results, total asset turnover has a positive and significant effect on financial performance.

The total asset turnover rate shows the efficiency of all company assets for sales. This ratio measures how much of an asset is used in an activity, or how often an asset changes in a certain period of time. If the ratio tends to rise, this situation is a condition where the company uses assets more effectively to increase sales, which will affect the company's profits. This research is in line with the research of [9] which proves that total asset turnover has a significant effect on company performance. However, this is in contrast to the research conducted by [6], which showed that total asset turnover had no effect on company performance.

\section{Effect of capital structure, firm size and total asset turnover on financial performance}

From the results of simultaneous testing, capital structure, firm size and total asset turnover have a significant effect on financial performance.

\section{VI.CONCLUSION}

After conducting hypothesis testing, it was determined that capital structure has a negative and statistically significant impact on financial performance, that firm size has no effect on financial performance, and that total asset turnover has a positive and statistically significant impact on financial performance. Furthermore, it demonstrates that the capital structure, business size, and total asset turnover all have a significant impact on financial performance in the same time period.

\section{REFERENCES}

[1] D. K. O. Kusumajaya, "Pengaruh Struktur Modal dan Pertumbuhan Perusahaan terhadap Profitabilitas dan Nilai Perusahaan pada Perusahaan Manufaktur di Bursa Efek
Indonesia," Unpubl. Thesis. Univ. Udayana, pp. 1-132, 2011, [Online]. Available: https://www.academia.edu/7689418/Pengaruh_Struktur_Modal_D an_Pertumbuhan_Perusahaan_Terhadap_Prof.

[2] H. Hartoyo, "Hubungan Current Ratio, Struktur Modal, dan Ukuran Perusahaan terhadap Kinerja Keuangan Perusahaan Pertambangan yang Terdaftar di BEI Periode 2014-2016," $J$. Maksipreneur Manajemen, Koperasi, dan Entrep., vol. 8, no. 1, p. 81, 2018, doi: 10.30588/jmp.v8i1.375.

[3] E. N. Zakiyah, M. A. Salim, and B. Wahono, "Pengaruh Struktur Modal dan Ukuran Perusahaan Terhadap Kinerja Keuangan (Studi Kasus Pada Perusahaan Makanan dan Minuman Yang Terdaftar di Bursa Efek Indonesia Tahun 2014-2017)," e-jurnal Ris. Manaj. Prodi Manaj. Fak. Ekon. dan Bisnis Unisma, pp. 86-97, 2018.

[4] J. T. A. Tambunan and B. Prabawani, "Pengaruh Ukuran Perusahaan, Leverage dan Struktur Modal Terhadap Kinerja Keuangan Perusahaan (Studi Pada Perusahaan Manufaktur Sektor Aneka Industri Tahun 2012-2016)," Diponegoro J. Soc. Polit., vol. 7, no. 2 , pp. 130-140, 2018, [Online]. Available: http://ejournals1.undip.ac.id/index.php.

[5] N. An Suci Azzahra, "Pengaruh Firm Size dan Leverage Ratio Terhadap Kinerja Keuangan pada Perusahaan Pertambangan," Jwem Stie Mikroskil, vol. 9, no. 1, pp. 13-20, 2019.

[6] D. Puji Rahayu, "Pengaruh Ukuran Perusahaan, Struktur Modal, Dan Likuiditas terhadap Kinerja Keuangan pada Perusahaan Makanan Dan Minuman Yang Tercatat Di Bursa Efek Indonesia ( Bei ) Tahun 2013-2017," J. Akunt. Dan Keuang. Kontemporer, vol. 2, no. 1, pp. 121-134, 2019, doi: http://dx.doi.org/10.30596\%2Fja kk.v2i1.5705.

[7] N. L. G. S. Fajaryani and E. Suryani, "Struktur Modal, Likuiditas, Dan Ukuran Perusahaan Terhadap Kinerja Keuangan Perusahaan," J. Ris. Akunt. Kontemporer, vol. 10, no. 2, pp. 74-79, 2018, doi: 10.23969/jrak.v10i2.1370.

[8] P. Lestari, "Pengaruh Likuiditas, Der, Firm Size, Dan Asset Turnover Terhadap Kinerja Keuangan," J. Neraca J. Pendidik. dan Ilmu Ekon. Akunt., vol. 4, no. 1, p. 1, 2020, doi: 10.31851/neraca.v4i1.3843.

[9] A. Yunita, J. Susyanti, and B. Wahono, "Pengaruh Analisis Current Ratio (Cr), Debt To Equity Ratio (Der) Dan Total Assets Turnover (Tato) Terhadap Penilaian Kinerja Keuangan Pada Ekonomi Kreatif Sub Sektor Fashion Di Kota Malang Tahun 2016-2018," e-Jurnal Ris. Manaj., pp. 1-17, 2020.

[10] Y. A. Nurcahya and R. P. Dewi, "Analisis Laporan Keuangan Sebagai Alat untuk Menilai Kinerja Keuangan Perusahaan pada PT Multi Bintang Indonesia Tbk," J. Ilm. Akunt. dan Keuang., vol. 9, no. 2, pp. 83-95, 2020, doi: 10.32639/jiak.v9i2.423.

[11] I. Fahmi, Manajemen Keuangan Perusahaan dan Pasar Modal. 2014.

[12] Sartono, Manajemen Keuangan Teori dan Aplikasi. Yogyakarta: BPFE, 2016.

[13] B. Mahmood, M. Iqbal, M. Zafar, and B. Khalid, "Textile Industry Socializing, Economic Gains and Capital Structure: A Case Study of Faisalabad, Pakistan," J. Appl. Environ. Biol. Sci., vol. 7, no. 9, pp. 1-7, 2017, [Online]. Available: https://www.researchgate.net/profile/Muhammad_Iqbal76/publicat ion/319502279_Textile_Industry_Socializing_Economic_Gains_a nd_Capital_Structure_A_Case_Study_of_Faisalabad_Pakistan/link s/59af76c1aca2720370736957/Textile-Industry-SocializingEconomic-Gains-an.

[14] M. Suharli, "STUDI EMPIRIS MENGENAI PENGARUH PROFITABILITAS, LEVERAGE, DAN HARGA SAHAM TERHADAP JUMLAH DIVIDEN TUNAI (Studi pada Perusahaan yang Terdaftar di Bursa Efek Jakarta Periode 20022003)," J. Manajemen, Akunt. Sist. Inf., vol. 6, no. 2, pp. 243-256, 2010, [Online]. Available: https://ejournal.undip.ac.id/index.php/ maksi/article/view/258.

[15] D. Mulyanti, Manajemen Keuangan Perusahaan, vol. 8, no. 1. 2017.

[16] A. Sri, M. Dewi, and A. Wirajaya, "Pengaruh Struktur Modal, Profitabilitas Dan Ukuran Perusahaan Pada Nilai Perusahaan," EJurnal Akunt., vol. 4, no. 2, pp. 358-372, 2013. 
International Journal of Research and Scientific Innovation (IJRSI) |Volume IX, Issue II, February 2022|ISSN 2321-2705

[17] C. Srimindarti, "Pengaruh Current Ratio,Total Assets Turnover, dan Return on Investment Terhadap Kinerja Perusahaan Pada Industri Food And Beverages Yang Terdaftar Di BEI .” 6(2):14758.," vol. 6, no. 2, pp. 147-158, 2009.

[18] L. F. A. Desiana, Analisis Laporan Keuangan (Teori dan
Pemahaman Materi). 2017.

[19] Sugiarto, Metodologi Penelitian Bisnis. In Yeskha (Ed.), Metodologi Penelitian Bisnis. 2017. 